\title{
Analisis Rasio Keuangan Untuk Menilai Kinerja Keuangan Pada Perusahaan Multifinance Yang Terdaftar Di Bursa Efek Indonesia Periode Tahun 2015-2019
}

\author{
Turmono $^{1}$, Mawarto ${ }^{2}$ \\ Dosen STIE Dharma Bumiputera \\ turmono217@gmail.com, mawarto@yahoo.com
}

\begin{abstract}
ABSTRAK
Tujuan penelitian ini adalah untuk mengetahui kinerja keuangan terbaik dan perbandingan kinerja keuangan pada perusahaan multifinance yang terdaftar di Bursa Efek Indonesia yang ditinjau dari analisis rasio likuiditas, rasio solvabilitas, rasio aktivitas dan rasio profitabilitas. Metode penelitian yang digunakan adalah analisis deskriptif dan analisis komparatif. Hasil penelitian berdasarkan hasil komparatif rasio selama 5 tahun yang di hitung dengan rasio likuiditas perusahaan yang memiliki CR paling baik adalah CFIN karena memiliki rasio tertinggi sebesar 230,15\% dan CSR paling baik adalah WOMF sebesar 13,44\%. Untuk rasio solvabilitas paling baik adalah CFIN dengan nilai rasio DAR dan DER terendah sebesar 55,93\% dan 126,93\%. Hasil rasio aktivitas menunjukan nilai RTO terbaik adalah WOMF karena memiliki rasio tertinggi sebesar 0,37 kali dan TATO terbaik adalah ADMF dengan nilai rasio tertinggi sebesar 0,32 kali. Dari hasil profitabilitas adalah ADMF karena memiliki rasio ROA dan ROE tertinggi sebesar 4,62\% dan 23,21\%. Dari total skor tahun 2015-2019 Peringkat pertama adalah ADMF dengan total 64 skor, peringkat kedua CFIN dengan total 84 skor dan peringkat ketiga WOMF dengan total 92 skor.
\end{abstract}

Kata Kunci : Analisis Rasio Keuangan, Kinerja Keuangan

\begin{abstract}
The objective of this research is to know the best financial performance and the financial performance ratio of multifinance companies listed at Indonesian Stock Exchange reviewed from the analysis of liquidity ratio, solvency ratio, activity ratio and profitability ratio. The method applied is descriptive and comparative methods. The result based on comparative method the ratio in 5 years calculated by the liquidity ratio of the company having the best CR is CFIN because it has the highest ratio of $230.15 \%$ and the best CSR is WOMF by 13.44\%. The best solvency ratio is CFIN with the lowest DAR and DER ratio is $55.9 \%$ and $126.93 \%$. Activity ratio result indicates the best RTO value is WOMF because it has the highest ratio by 0.37 times and the best TATO is ADMF with highest ratio of 0.32 times. The best profitability ratio is achieved by ADMF because it has the highest $R O A$ and ROE ratios of $4.62 \%$ and $23.21 \%$. Of total score in 2015-2019 periods, the first rank is occupied by ADMF with score 64, CFIN in the second one with score 84 and WOMF in the third with score 92.
\end{abstract}

Keywords:, Financial Ratio Analysis, Financial Performance

\section{PENDAHULUAN}

Kondisi perusahaan yang baik merupakan kekuatan untuk mampu bertahan dan berkembang dalam persaingan bisnis di dunia global yang semakin maju ini. Berbagai macam upaya yang dilakukan untuk mencapai tujuan perusahaan. Perusahaaan harus berusaha dalam mengelola sumber daya yang dimiliki dengan efisien dan efektif agar perusahaan dapat mewujudkan tujuan perusahaan. Tujuan perusahaan secara umum untuk memaksimalkan laba dan mengurangi kerugian yang dapat mengancam kelangsungan hidup perusahaan tersebut. Kelangsungan hidup perusahaan dapat dilihat dari kondisi keuangan perusahaan, informasi mengenai kondisi keuangan perusahaan dapat diketahui dari laporan keuangan yang disusun setiap akhir periode waktu tertentu.

Dalam membuat keputusan kedepan perusahaan menggunakan laporan keuangan sebagai salah satu sumber informasi tentang apa yang mungkin akan terjadi pada masa yang akan datang, akan tetapi laporan keuangan hanya menyajikan informasi tentang apa yang sudah terjadi karena sifatnya historis, sehingga timbul kesenjangan kebutuhan informasi. Maka laporan keuangan harus dianalisis dengan cara mengolah kembali laporan keuangan untuk mengetahui berbagai hal yang berhubungan 
dengan kesehatan finansial perusahaan dan dapat mendukung dalam pengambilan keputusan.

Seperti berita yang dilansir oleh beritasatu.com Senin 7 Oktober 2019 dengan judul persaingan industri pembiayaan dinilai semakin ketat, berita ini menjelaskan peta persaingan pada industri pembiayaan semakin ketat dan menuntut perusahaan berpikir lebih keras untuk menentukan strategi bisnisnya dalam menghadapi persaingan mendapatkan porsi konsumen pembiayaan. Menteri Perencanaan Pembangunan Nasional Bambang Brodjonegoro mengatakan pihaknya ingin mendorong multifinance menyikapi masa depan. bagaimana multifinance menyikapi ekonomi digital, dengan fintech atau pembiayaan dari e-commerce, Berdasarkan data laporan kinerja perusahaan multifinance yang dirilis oleh Otoritas Jasa Keuangan (OJK), penyaluran pembiayaan hingga Juni 2019 mencapai Rp 463,38 triliun. Angka ini tumbuh sekitar 4,47\% dari Juni 2018 yang mencapai Rp 443,54 triliun. Dari total angka tersebut sebanyak $22 \%$ disalurkan untuk kendaraan bermotor roda dua dan $41,6 \%$ untuk kendaraan roda empat. Sisanya disalurkan untuk barang konsumsi lainnya, barang produktif, barang infrastruktur, jasa serta piutang usaha. Sedangkan total aset perusahaan pembiayaan di Indonesia mengalami pertumbuhan sebesar $2,77 \%$ pada Juni 2019 (yoy). Total aset pada Juni 2018 tercatat Rp 499,3 triliun, sedangkan untuk Juni 2019 tercatat sebesar Rp 513, 2 triliun.

Dalam menjalankan roda bisnisnya, perusahaan pembiayaan sangat bergantung dari sumber pendanaan, baik dari bank, investor dalam negeri maupun luar negeri. Kesehatan kinerja keuangan perusahaan pembiayaan menjadi syarat mutlak bagi perusahaan yang ingin mendapatkan sumber pendanaan dari pihak eksternal. OJK sebagai regulator institusi keuangan di Indonesia telah menetapkan batas minimum kondisi finansial sebuah perusahaan pembiayaan untuk dapat dikategorikan sebagai perusahaan yang sehat secara finansial. Hal itu dituangkan dalam Peraturan OJK Nomor 35/POJK.05/2018 Tentang Penyelenggaraan Usaha Perusahaan Pembiayaan. Peraturan ini merupakan penyempurnaan dari Peraturan OJK Nomor 29/POJK.05/2014 yang memiliki tujuan untuk meningkatkan peranan perusahaan pembiayaan dalam perekonomian nasional, meningkatkan pengaturan prudensial, dan meningkatkan perlindungan konsumen.

Rasio keuangan untuk menilai kinerja keuangan dalam kosepnya akuntansi dikenal analisa rasio keuangan yang berguna untuk mengukur atau menilai kinerja keuangan secara komersial, sedangkan dalam praktiknya atau sesuai dengan pedoman POJK rasio keuangan digunakan untuk menilai tingkat kesehatan perusahaan pembiayaan dengan beberapa komponen sesuai dengan praktik bisnis usaha pembiayaan. Analisis rasio-rasio yang digunakan dalam teori dan praktik serta rasio yang digunakan dalam penelitian ini yaitu rasio likuiditas, rasio solvabilitas, rasio aktivitas dan rasio profitabilitas.

Lalu dari berita terbaru oleh investor.id Kamis tanggal 07 November 2019 dengan judul Kinerja Industri Multifinance Terpengaruh Perilaku Milenial, berita ini menjelaskan Industri multifinance mencatatkan rapor merah per kuartal III-2019. Penyaluran pembiayaan melambat dan hanya mampu menorehkan pertumbuhan sebesar $3,53 \%$ secara tahunan. Salah satu penyebabnya adalah fenomena perubahan perilaku konsumen, khususnya generasi milenial. Ketua Umum Asosiasi Perusahaan Pembiayaan Indonesia (APPI) mengatakan, perubahan perilaku konsumen salah satunya dipengaruhi hadirnya tranportasi daring (dalam jaringan). Pelayanan transportasi tersebut menawarkan kemudahan dan efisiensi lebih dibandingkan harus menggunakan kendaraan pribadi. Hal tersebut menjadi tantangan industri multifinance saat ini. Fenomena tersebut akhirnya mendorong masyarakat untuk mengurungkan niat membeli kendaraan bermotor. Padahal, lini bisnis tersebut berkontribusi hingga $66,05 \%$ terhadap total pembiayaan, secara tidak langsung pembiayaan multifinance terperosok dan hanya mampu mencapai Rp 451,12 triliun atau tumbuh 3,53\% per kuartal III2019.

Sementara lembaga pemeringkat internasional, Moody's Investor Service (Moody's) dalam cnbcindonesia.com Senin tanggal 21 Oktober 2019 melalui laporannya yang bertajuk "Vehicle finance companies - Indonesia, India: Liquidity risks lower for Indonesian lenders due to better profitability, asset quality." Analis Senior sekaligus Wakil Presiden Moody's mengatakan risiko likuiditas lebih rendah untuk perusahaan pembiayaan kendaraan di Indonesia, meskipun lebih bergantung pada pendanaan jangka pendek, berkat profitabilitas dan kualitas aset yang lebih kuat. Profitabilitas perusahaan pembiayaan kendaraan Tanah Air lebih baik didorong oleh fokus bisnis pelaku industri pada segmen dengan imbal hasil tinggi, dan struktur industri dengan kompetisi terbatas dari bank. Hal ini membantu suku bunga kredit perusahaan tetap tinggi. Imbal hasil yang lebih besar tersebut kemudian membantu perusahaan untuk menghapus dan menyelesaikan aset bermasalah lebih cepat yang berujung pada kualitas aset yang 
lebih baik. Meskipun demikian, Moody's menekankan bahwa ketergantungan pada pendanaan jangka pendek dan likuiditas rendah membuat perusahaan pembiayaan kendaraan di Indonesia riskan akan perubahan kondisi yang mendadak.

Selanjutnya dari berita terbaru oleh merdeka.com Rabu tanggal 11 Maret 2020 dengan judul Virus Corona Tekan Kinerja Perusahaan Pembiayaan, berita ini menjelaskan penyebaran virus corona membuat kinerja ekonomi tertekan. infeksi virus asal Wuhan, China tersebut diprediksi bakal mempengaruhi kinerja perusahaan pembiayaan. sektor yang paling terpukul adalah pembiayaan otomotif. Kepala Departemen Pengawasan IKNB OJK mengatakan, penurunan kinerja pembiayaan dipengaruhi oleh mispersepsi putusan Mahkamah Konstitusi (MK) mengenai perjanjian fidusia. Untuk otomotif tahun ini diprediksi melambat karena memang industrinya tengah mengalami penurunan. Prospek kinerja perusahaan pembiayaan tahun 2020 secara keseluruhan juga diperkirakan melambat. Paling tidak pertumbuhan perusahaan pembiayaan akan tidak lebih besar atau sama seperti tahun lalu yang hanya $4 \%$.

Dari fenomena-fenomena diatas kinerja perusahaan perlu memperhatikan risiko tersebut agar pengurus perusahaan dapat mengetahui keadaan keuangan yang dimiliki sehingga bisa menentukan rencana strategis untuk masa yang akan datang.

Media yang dapat dipakai untuk menilai kinerja perusahaan adalah laporan keuangan. Menurut Kasmir (2015:7) laporan keuangan adalah laporan yang menunjukkan kondisi keuangan perusahaan pada saat ini atau dalam suatu periode tertentu. Maksud laporan keuangan yang menunjukkan kondisi keuangan perusahaan saat ini adalah merupakan kondisi terkini. laporan keuangan tersebut digunakan untuk membantu para manajer dalam menilai kinerja perusahaan sehingga dapat mengambil keputusan yang tepat. Secara periodik perusahaan mengeluarkan laporan keuangan yang dibuat oleh bagian akuntansi dan diberikan kepada pihak-pihak yang berkepentingan, misalnya pemilik perusahaan, manajemen, kreditor dan pemerintah, laporan keuangan terdiri dari laporan posisi keuangan, laporan laba rugi, laporan perubahan ekuitas, laporan arus kas dan laporan keuangan.

Dalam interpretasi dan analisis laporan keuangan suatu perusahaan, diperlukan adanya ukuran atau standar tertentu. Ukuran yang sering digunakan dalam analisis keuangan adalah rasio. Analisis rasio dapat menggambarkan posisi, kondisi maupun hasil kerja yang telah dicapai, analisis rasio dapat diklasifikasikan dalam berbagai jenis, diantaranya yaitu rasio likuiditas, rasio aktivitas, rasio solvabilitas, dan rasio profitabilitas, dengan adanya rasio keuangan ini dapat diketahui tingkat likuiditas, aktivitas, solvabilitas, dan profitabilitas suatu perusahaan dan dapat memberikan gambaran perusahaan yang sebenarnya sehingga dapat mengukur kinerja keuangan perusahaan. Maka oleh karena pentingnya menilai kinerja keuangan suatu perusahaan.

\section{Tujuan Penelitian}

Berdasarkan uraian latar belakang sebagaimana dikemukakan, maka tujuan penelitian ini sebagai berikut:

1) Untuk mengetahui kinerja keuangan terbaik perusahaan multifinance yang terdaftar di Bursa Efek Indonesia yang ditinjau dengan menggunakan analisis rasio likuiditas, rasio solvabilitas, rasio aktivitas, dan rasio profitabilitas.

2) Untuk mengetahui perbandingan kinerja keuangan perusahaan multifinance yang terdaftar di Bursa Efek Indonesia yang ditinjau dengan menggunakan analisis rasio likuiditas, rasio solvabilitas, rasio aktivitas, dan rasio profitabilitas.

\section{TINJAUAN PUSTAKA}

\section{Pengertian Akuntansi}

Pengertian akuntansi menurut Effendi (2015:1) adalah proses pengidentifikasian, pengukuran, pencatatan, penggolongan, dan pengikhtisaran serta pelaporan informasi keuangan dalam ukuran moneter dalam suatu perusahaan atau organisasi yang ditujukan kepada pihak-pihak yang berkepentingan dalam rangka pengambilan keputusan. Adapun menurut Weygandt, Kimmel dan dkk (2018:4) pengertian akuntansi adalah suatu sistem informasi yang mengidentifikasikan, mencatat, dan mengkomunikasikan peristiwa-peristiwa ekonomi dari suatu organisasi kepada para pengguna yang berkepentingan. Berdasarkan Standar Akuntansi Keuangan perusahaan pembiayaan di atur dalam PSAK No. 30 tahun 2012.

\section{Pengertian Bursa Efek Indonesia (BEI)}

Bursa Efek Indonesia (BEI) berdiri berkat penggabungan dua bursa yang telah lebih dulu ada di Indonesia, yaitu Bursa Efek Jakarta (BEJ) dan Bursa Efek Surabaya (BES). Atau dalam bahasa Inggris di disebut dengan Indonesia Stock Exchange (IDX). Kata IDX sebenarnya merujuk ke singkatan ini, sekaligus karena situs resmi bursa efek Indonesia adalah www.idx.co.id. Dalam penelitian ini laporan keuangan perusahaan multifinance diperoleh dari 
website resmi perusahaan multifinance dan website resmi BEI.

\section{Pengertian Laporan Keuangan}

Laporan keuangan menurut Standar Akuntansi Keuangan (2015:2) adalah bagian dari proses pelaporan keuangan. Laporan keuangan yang lengkap biasanya meliputi neraca, laporan laba rugi, laporan perubahan posisi keuangan (yang dapat disajikan dalam berbagai cara misalnya sebagai laporan arus kas atau laporan arus dana) catatan dan laporan lain serta materi penjelasan yang merupakan bagian integral dari laporan keuangan. Menurut Fahmi (2017:22) laporan keuangan merupakan suatu informasi yang menggambarkan kondisi keuangan suatu perusahaan, dimana selanjutnya itu akan menjadi suatu informasi yang menggambarkan tentang kinerja suatu perusahaan. Adapun pengertian laporan keuangan menurut Yadiati (2007:51) adalah informasi keuangan yang disajikan dan disiapkan oleh manajemen dari suatu perusahaan kepada pihak internal dan eksternal, yang berisi seluruh kegiatan bisnis satu kesatuan usaha yang merupakan salah satu alat pertanggungjawaban dan komunikasi manajemen kepada pihak-pihak yang membutuhkannya.

\section{Pengertian Kinerja Keuangan}

Menurut Fahmi (2017:2), Kinerja keuangan merupakan gambaran dari pencapaian keberhasilan perusahaan dapat diartikan sebagai hasil yang telah dicapai atas berbagai aktivitas yang telah dilakukan. Dapat dijelaskan bahwa kinerja keuangan adalah suatu analisis yang dilakukan untuk melihat sejauh mana suatu perusahaan telah melaksanakan dengan menggunakan aturan-aturan pelaksanaan keuangan secara baik dan benar. Dan menurut Rudianto (2013: 189), kinerja keuangan adalah hasil atau prestasi yang telah dicapai oleh manajemen perusahaan dalam menjalankan fungsinya mengelola aset perusahaan secara efektif selama periode tertentu.

\section{Pengertian Analisis Laporan Keuangan}

Pengertian analisis laporan keuangan menurut Harahap (2018:190) adalah suatu proses menguraikan pos-pos laporan keuangan menjadi unit informasi yang lebih kecil dan melihat hubungan yang bersifat signifikan antara data kuantitatif maupun data non kuantitatif yang bertujuan untuk mengetahui kondisi keuangan yang lebih jelas sebagai proses dalam menghasilkan keputusan yang tepat. Sedangkan menurut Soemarso (2005:380) analisis laporan keuangan adalah hubungan antara suatu angka dalam laporan keuangan dengan angka lain yang mempunyai makna atau dapat menjelaskan arah perubahan (trend) suatu fenomena. Angka-angka dalam laporan keuangan akan sedikit artinya kalau dilihat secara sendiri-sendiri. Dengan analisis, pemakai laporan keuangan lebih mudah menginterpretasikannya. Dan menurut Subramanyam (2017: 3) analisis laporan keuangan merupakan bagian yang tidak terpisahkan dan penting dari bidang analisis bisnis yang lebih luas.

\section{Pengertian Analisis Rasio Keuangan}

Menurut Subramanyan dan Wild (2010:40) analisis rasio merupakan satu alat analisis keuangan yang paling populer dan banyak digunakan. Namun, perannya sering disalahpahami dan sebagai konsekuensinya, kepentingannya sendiri sering dilebih-lebihkan. Sebagai rasio menyatakan hubungan matematis antara dua kuantitas. Menurut Subramanyan dan Wild (2010:40) analisis rasio merupakan satu alat analisis keuangan yang paling populer dan banyak digunakan. Namun, perannya sering disalahpahami dan sebagai konsekuensinya, kepentingannya sendiri sering dilebih-lebihkan. Sebagai rasio menyiatkan hubungan matematis antara dua kuantitas. Sedangkan menurut Jumingan (2011:242) analisis rasio keuangan merupakan analisis dengan jalan membandingkan satu pos dengan pos laporan keuangan lainnya baik secara individu maupun bersama - sama guna mengetahui hubungan diantara pos tertentu, baik dalam neraca maupun laporan laba rugi.

\section{Rasio Likuiditas (Liquidity Ratio)}

Menurut Fahmi (2017:59) rasio likuiditas adalah kemampuan suatu perusahaan memenuhi kewajiban jangka pendeknya secara tepat waktu. Sedangkan menurut Kasmir (2015:130) rasio likuiditas atau sering juga disebut dengan nama rasio modal kerja merupakan rasio yang digunakan untuk mengukur seberapa likuidnya suatu perusahaan. Tujuan dari rasio likuiditas adalah untuk melihat kemampuan perusahaan untuk memenuhi kewajiban jangka pendek. Semakin tinggi angka tersebut, maka akan semakin baik.

\section{Rasio Solvabilitas (Leverage Ratio)}

Menurut Soemarso (2010:389) rasio solvabilitas adalah rasio untuk mengukur kemampuan perusahaan dalam melunasi kewajibannya. Sedangkan menurut Kasmir (2015:151) rasio solvabilitas atau laverage ratio merupakan rasio yang digunakan untuk mengukur sejauh mana aktiva perusahaan dibiayai dengan utang. Artinya berapa besar beban utang yang ditanggung perusahaan dibandingkan dengan aktivanya. Dalam arti luas dikatakan bahwa rasio solvabilitas digunakan untuk mengukur 
kemampuan perusahaan untuk membayar seluruh kewajibannya, baik jangka pendek maupun jangka panjang apabila perusahaan dibubarkan (dilikuidasi).

\section{Rasio Aktivitas (Activity Ratio)}

Menurut Soemarso (2015:392) rasio aktivitas adalah mengukur efisien tidaknya pengelolaan sumber daya yang dimiliki perusahaan. Analisis ini menganggap perlunya suatu keseimbangan yang tepat antara investasi dalam setiap pos aktiva (persediaan, piutang dagang, aktiva tetap, dan lain-lain) dengan hasil yang diperoleh dari investasi tersebut.

\section{Rasio Profitabilitas (Provitability Ratio)}

Menurut Kasmir (2015:196) rasio profitabilitas merupakan rasio untuk menilai kemampuan perusahaan dalam mencari keuntungan. Rasio ini juga memberikan ukuran tingkat efektivitas manajemen suatu perusahaan. Hal ini ditunjukkan oleh laba yang dihasilkan dari penjualan dan pendapatan investasi. Intinya adalah penggunaan rasio ini menunjukkan efisiensi perusahaan.

\section{Model Penelitian}

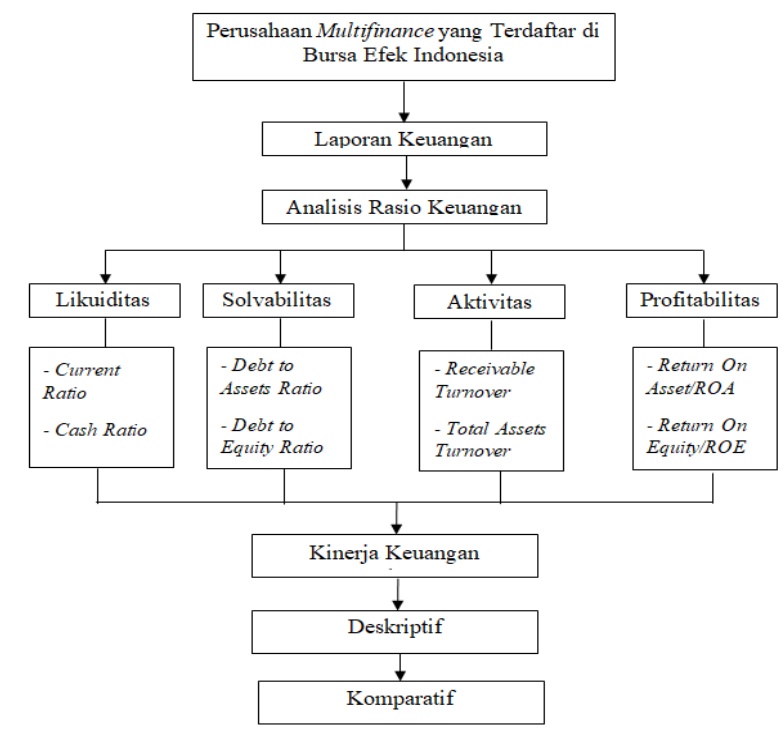

Sumber : Data diolah

Gambar 1. Kerangka pemikiran

\section{METODE PENELITIAN}

\section{Populasi dan Sampel}

Populasi dalam penelitian ini sebanyak 16 perusahaan Multifinance yang terdaftar di Bursa Efek Indonesia periode 2015-2019. Teknik pengambilan sampel (sampling) dalam penelitian ini diambil dengan menggunakan pendekatan nonprobability sampling, yaitu teknik pengambilan sampel yang tidak memberi peluang atau kesempatan sama bagi setiap unsur atau anggota populasi untuk dipilih menjadi sampel. (Sugiyono, 2019:131), dan dengan metode sampling purposive. sampling purposive adalah teknik penentuan sampel dengan pertimbangan tertentu. (Sugiyono, 2019:133). Adapun kriteria-kriteria yang ditetapkan dalam penelitian ini adalah sebagai berikut: 1) Perusahaan multifinance yang terdaftar di Bursa Efek Indonesia selama tahun 2015-2019. 2) Perusahaan multifinance yang memiliki data laporan keuangan lengkap di Bursa Efek Indonesia serta dipublikasikan pada website resmi perusahaan masing-masing pada periode 2015-2019. 3) Perusahaan multifinance yang terdaftar di Bursa Efek Indonesia (BEI) sebelum tanggal 31 Desember 2004 (tanggal IPO) dan tidak delisting selama periode pengamatan tahun 2015-2019. 4) Perusahaan multifinance yang tercatat di BEI yang terafiliasi dengan perbankan dan memiliki total aset 8 triliun keatas pada tahun 2019.

\section{Metode Analisis Data}

Metode analisis deskriptif dan analisis komparatif dipilih untuk penelitian ini. Teknik ini digunakan dengan cara menghitung rasio keuangan dan membandingkan laporan - laporan keuangan antar periode dan antar perusahaan. Dalam penelitian ini pengukuran terhadap kinerja keuangan perusahaan multifinance yang akan di teliti dengan menggunakan rasio dengan rumus rasio sebagai berikut :

\section{Rasio Likuiditas}

Rasio likuiditas merupakan rasio yang digunakan untuk mengukur seberapa likuidnya suatu perusahaan.

\section{Rasio Lancar (Current Ratio)}

Rasio Lancar atau current ratio merupakan rasio untuk mengukur kemampuan perusahaan dalam membayar kewajiban jangka pendek atau utang yang segera jatuh tempo pada saat ditagih secara keseluruhan. Rumus yang digunakan untuk menghitung rasio lancar sebagai berikut:

$$
\text { Current Ratio }=\frac{\text { Aktiva Lancar }(\text { Current Assets })}{\text { Utang Lancar }(\text { Current Liabilities })}
$$

\section{Rasio Kas (Cash Ratio)}

Rasio kas atau cash ratio merupakan alat yang digunakan untuk mengukur seberapa besar uang kas yang tersedia untuk membayar kewajiban jangka 
pendeknya. Rumus yang digunakan untuk menghitung rasio kas sebagai berikut:

$$
\text { Cash Ratio }=\frac{\text { Cashor Cash Equivalent }}{\text { Current Liabilities }} \rightarrow(2)
$$

\section{Rasio Solvabilitas}

Rasio solvabilitas adalah rasio untuk mengukur kemampuan perusahaan dalam melunasi kewajibannya.

\section{Rasio hutang terhadap aset (Debt to Asset Ratio)}

Rasio utang terhadap aset atau Debt to Asset Ratio merupakan rasio utang yang digunakan untuk mengukur perbandingan antara total utang dengan total aset. Rumus yang digunakan untuk menghitung rasio hutang terhadap aset sebagai berikut :

$$
\text { Debt to asset ratio }=\frac{\text { Total Utang (Debt) }}{\text { Total Aset }(\text { Assets })} \rightarrow \text { (3) }
$$

\section{Rasio hutang terhadap modal (Debt to Equity} Ratio)

Rasio hutang terhadap modal atau Debt to Equity Ratio merupakan rasio yang digunakan untuk menilai utang dengan ekuitas. Rasio ini dicari dengan cara membandingkan antara seluruh utang, termasuk utang lancar dengan seluruh ekuitas. Rumus yang digunakan untuk menghitung rasio hutang terhadap modal sebagai berikut :

$$
\text { Debt to equity ratio }=\frac{\text { Total Utang (Debt) }}{\text { Ekuitas }(\text { Equity })} \rightarrow \text { (4) }
$$

\section{Rasio Aktivitas}

Rasio aktivitas adalah rasio yang mengukur seberapa efektif perusahaan dalam memanfaatkan sumber daya yang ada.

\section{Perputaran Piutang (Receivable Turnover)}

Perputaran Piutang rasio ini berguna untuk menunjukkan berapa kali suatu perusahaan menagih piutangnya dalam suatu periode dan efisiensi perusahaan dalam mengelola piutangnya. Rumus untuk mencari perputaran piutang adalah sebagai berikut:

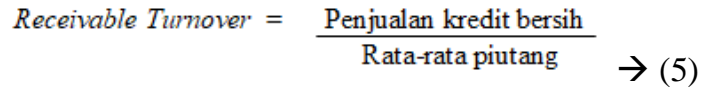

\section{Perputaran Total Aset (Total Assets Turnover)}

Perputaran total aset merupakan rasio yang menunjukkan efisiensi penggunaan total aset. Rumus untuk mencari perputaran total aset adalah sebagai berikut :

$$
\text { Total Assets Turnover }=\frac{\text { Penjualan Bersih }}{\text { Rata-rata total aktiva }} \rightarrow(6
$$

\section{Rasio Profitabilitas}

Rasio profitabilitas merupakan rasio untuk menilai kemampuan perusahaan dalam mencari keuntungan.

\section{Hasil Pengembalian Aset (Return On Assets)}

Hasil pengembalian aset atau return on assets (ROA) merupakan rasio yang menunjukkan hasil (return) atas jumlah aset yang digunakan dalam perusahaan. Rumus untuk mencari hasil pengembalian investasi adalah sebagai berikut :

$$
\text { Retum On Assets }=\frac{\text { Earning After Interest and Tax }}{\text { Total Assets }} \rightarrow(7)
$$

\section{Hasil Pengembalian Ekuitas (Return On Equity)}

Hasil pengembalian ekuitas atau return on equity atau rentabilitas modal sendiri merupakan rasio untuk mengukur laba bersih sesudah pajak dengan modal sendiri. Rasio ini menunjukkan efisiensi penggunaan modal sendiri. Rumus untuk mencari hasil pengembalian ekuitas adalah sebagai berikut :

Return On Equity $=\frac{\text { Earning After Interest and Tax }}{\text { Equity }} \rightarrow(8)$

\section{PEMBAHASAN DAN PEMBAHASAN}

\section{Likuiditas Masing-masing Perusahaan Dan Komparatifnya}

Tabel 1. Hasil Perhitungan Rasio Likuiditas

\begin{tabular}{ccccccc}
\hline \multicolumn{7}{c}{ Rasio Likuiditas } \\
(Hasil Data Berdasarkan Persentasi)
\end{tabular}

Sumber : Data Diolah

\section{PT Clipan Finance Indonesia Tbk}

Berdasarkan data hasil penelitian rasio likuiditas dapat dijelaskan kinerja keuangan perusahaan dari rasio likuiditas pada PT Clipan Finance Indonesia Tbk sebagai berikut. Kinerja keuangan PT Clipan Finance Indonesia Tbk sesuai dengan data hasil penelitian selama 5 tahun berdasarkan current ratio (CR) setiap tahunnya menunjukkan angka di atas 
200\%. Kecuali pada tahun 2017 CR sebesar 188,64\% yang artinya setiap $100 \%$ kewajiban lancar di jamin oleh $188,64 \%$ aset lancarnya. Dimana CR pada tahun 2017 tersebut berada dibawah CR selama 5 tahun berjalan, hal tersebut disebabkan adanya kenaikan signifikan pada kewajiban lancar yang tidak sebanding dengan kenaikan aset lancarnya. Dengan demikian CR PT Clipan Finance Indonesia Tbk selama 5 tahun berjalan masih dianggap mampu dalam memenuhi kewajiban jangka pendeknya. Walaupun tidak ada standar khusus untuk menentukan CR yang paling baik, namun untuk prinsip kehati-hatian, maka besarnya CR sekitar $200 \%$ dianggap baik. Berdasarkan teori yang ada semakin tinggi CR maka semakin baik kinerja keuangan perusahaan.

Untuk hasil perhitungan cash ratio (CSR) PT Clipan Finance Indonesia Tbk selama 5 tahun berjalan ratarata berada pada angka $1 \%$. Kecuali CSR pada tahun 2017 yang berada pada angka 0,56\% yang artinya setiap $100 \%$ kewajiban lancar hanya dijamin oleh $0,56 \%$ kas dan setara kas. Penurunan CSR pada tahun 2017 tersebut disebabkan oleh turunnya jumlah kas dan setara kas dan naiknya kewajiban lancar. Berdasarkan hasil CSR pada 5 tahun kemampuan perusahaan untuk memenuhi kewajiban jangka pendeknya memerlukan waktu apabila menggunakan kas. Walaupun CSR yang besar tidak baik juga untuk perusahaan karena adanya dana yang tidak digunakan secara optimal. Hasil komparatif waktu rasio likuiditas PT Clipan Finance Indonesia Tbk yang diukur dengan CR rasio paling baik ada pada tahun 2016 karena memiliki CR tertinggi sebesar 294,46\% yang disebabkan karena nilai aset lancarnya lebih besar dari kewajiban lancarnya dan CSR terbaik di tahun 2019 karena memiliki rasio tertinggi sebesar $1,96 \%$.

\section{PT Adira Dinamika Multi Finance Tbk}

Berdasarkan data hasil penelitian rasio likuiditas dapat dijelaskan kinerja keuangan perusahaan dari rasio likuiditas pada PT Adira Dinamika Multi Finance Tbk sebagai berikut. Kinerja keuangan PT Adira Dinamika Multi Finance Tbk sesuai dengan data hasil penelitian selama 5 tahun berdasarkan current ratio (CR) menunjukkan hasil diatas $100 \%$. Pada tahun 2015 CR sebesar 124,35\%, lalu turun pada tahun 2016 menjadi 123,74\%, tahun 2017 meningkat menjadi $130,15 \%$ yang disebabkan oleh kenaikan aset lancarnya yang lebih besar dibandingkan dengan kewajiban lancarnya. Pada tahun 2018 CR sebesar 137,90 dan tahun 2019 CR menurun kembali menjadi $134,77 \%$ yang artinya setiap $100 \%$ kewajiban lancar dijamin oleh $134,77 \%$ aset lancarnya. Walaupun tren rasionya cenderung fluktuatif karena mengalami kenaikan dan penurunan setiap tahunnya. Dengan hasil CR diatas $100 \%$ selama 5 tahun berjalan maka dengan demikian CR PT Adira Dinamika Multi Finance Tbk masih dianggap mampu dalam memenuhi kewajiban jangka pendeknya.

Untuk cash ratio (CSR) PT Adira Dinamika Multi Finance.Tbk selama 5 tahun menunjukkan hasil yang berfluktuatif. Untuk 2 tahun pertama CSR diatas $4 \%$ pada tahun 2015 dan 2016. Lalu terjadi peningkatan pada tahun 2017 menjadi 10,06\% yang di sebabkan oleh naiknya kas dan setara kas. Pada tahun 2018 rasio turun sebesar 2,46\%, angka tersebut diperoleh dari hasil pengurangan (10,06\%-7,60\%) turunnya CSR yang disebabkan oleh turunnya kas dan setara kas sementara kewajiban lancarnya meningkat. Pada tahun 2019 CSR mengalami kenaikan menjadi $12,30 \%$. Karena kas dan setara kas juga utang lancar terus naik dan turun dalam 5 tahun berjalan, menyebabkan kemampuan kas dan setara kas PT Adira Dinamika Multi Finance Tbk dalam melunasi utang lancar tidak dapat di jamin setiap tahunnya. Hasil komparatif waktu rasio likuiditas PT Adira Dinamika Multi Finance Tbk yang diukur dengan CR dan CSR memiliki CR paling baik pada tahun 2018 karena memiliki CR tertinggi sebesar $137,90 \%$ yang disebabkan karena nilai aset lancarnya lebih besar dari kewajiban lancarnya dan CSR terbaik di tahun 2019 karena memiliki rasio tertinggi sebesar $12,30 \%$.

\section{PT Wahana Ottomitra Multiartha Tbk.}

Berdasarkan data hasil penelitian rasio likuiditas dapat dijelaskan kinerja keuangan perusahaan dari rasio likuiditas pada PT Wahana Ottomitra Multiartha Tbk sebagai berikut. Kinerja keuangan PT Wahana Ottomitra Multiartha Tbk sesuai dengan data hasil penelitian selama 5 tahun berdasarkan current ratio (CR) setiap tahunnya mengalami fluktuatif tetapi tidak terlalu siginifikan perbedaannya, karena setiap tahunnya menunjukkan hasil diatas 100\%. CR tahun 2015 sebesar 122,86\%, tahun 2016 sebesar 116,56\% menunjukkan bahwa terjadi penurunan yang disebabkan oleh kenaikan kewajiban lancar yang lebih besar dibandingkan dengan kenaikan aset lancarnya. Pada tahun 2017 mengalami peningkatan sebesar 117,40 , lalu tahun 2018 menurun menjadi sebesar $116,85 \%$ dan tahun 2019 meningkat kembali menjadi 123,09\% yang artinya bahwa dari setiap Rp. 1,- kewajiban lancar PT Wahana Ottomitra Multiartha Tbk dijamin oleh Rp. 1,23,- aset lancar atau setiap $100 \%$ kewajiban lancar dijamin oleh 123,09\% aset lancar perusahaan. Jadi meskipun terjadi peningkatan dan penurunan nilai CR 
dari periode 2015-2019 secara umum kemampuan PT Wahana Ottomitra Multiartha dalam memenuhi kewajiban jangka pendeknya sudah baik dengan nilai rata-rata rasio lebih dari $1(>1)$ atau $100 \%$ karena semakin besar perbandingan nilai aset lancar dan hutang lancar maka semakin tinggi kemampuan perusahaan dalam menutupi kewajiban lancar atau jangka pendeknya.

Untuk cash ratio (CSR) PT Wahana Ottomitra Multiartha selama periode tahun 2015 sampai dengan 2019 menunjukkan hasil yang juga berfluktuatif. Rasio kas tahun 2015 sebesar 20,19\% lalu menurun sebesar 10,47\%, sehingga CSR pada tahun 2016 sebesar 9,72\%, hal ini di sebabkan oleh penurunan kas dan setara kas tetapi kewajiban lancarnya meningkat dari tahun 2015. Pada tahun 2017 dan 2018 CSR meningkat sebesar 10,52 dan 16,74\% lalu menurun kembali tahun 2019 CSR menjadi sebesar $11,45 \%$ yang artinya setiap $100 \%$ kewajiban lancar dijamin oleh $11,45 \%$ kas dan setara kas. Karena kas dan setara kas juga utang lancar terus naik dan turun dalan 5 tahun berjalan, menyebabkan kemampuan kas dan setara kas PT Wahana Ottomitra Multiatha Tbk dalam melunasi utang lancar tidak dapat di jamin setiap tahunnya. Hasil komparatif waktu rasio likuiditas PT Wahana Ottomitra Multiartha Tbk yang diukur dengan CR dan CSR memiliki CR paling baik pada tahun 2019 karena memiliki CR tertinggi sebesar $123,09 \%$ yang disebabkan karena nilai aset lancarnya lebih besar dari kewajiban lancarnya dan CSR terbaik di tahun 2015 karena memiliki rasio tertinggi sebesar 20,19\%.

\section{Pembahasan Komparatif Likuiditas Perusahaan}
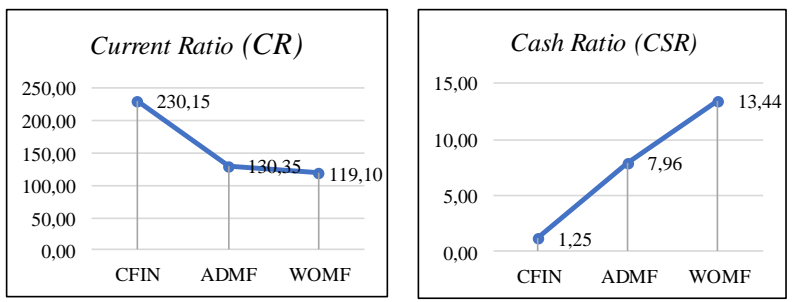

Sumber : Data Diolah

\section{Gambar 2. Grafik Komparatif Rasio Likuiditas Perusahaan}

Dari hasil komparatif masing-masing perusahaan dengan industri sejenis menunjukkan bahwa dari hasil perhitungan rasio likuiditas yang dihitung menggunakan current ratio (CR) dan cash ratio (CSR), perusahaan yang memiliki CR paling baik adalah PT Clipan Finance Indonesia Tbk karena memiliki rasio rata-rata tertinggi diantara perusahaan lainnya sebesar $230,15 \%$. Namun untuk perhitungan
CSR PT Wahana Ottomitra Multiartha Tbk memiliki rata-rata paling baik karena nilai rasionya paling tinggi dibandingkan PT Clipan Finance Indonesia dan PT Adira Dinamika Multi Finance yaitu sebesar $13,44 \%$, hal ini disebabkan karena nilai kas dan setara kas terhadap kewajiban lancarnya lebih tinggi dibandingkan perusahaan sejenis lainnya.

Pembahasan Masing-masing Solvabilitas Perusahaan Dan Komparatifnya

Tabel 2 Hasil Perhitungan Rasio Solvabilitas

\begin{tabular}{cccccc}
\hline \multicolumn{7}{c}{ Rasio Likuiditas } \\
(Hasil Data Berdasarkan Persentasi)
\end{tabular}

Sumber : Data Diolah

\section{PT Clipan Finance Indonesia Tbk}

Berdasarkan hasil perhitungan rasio solvabilitas yang diukur menggunakan Debt to Asset Ratio (DAR) dan Debt to Equity Ratio (DER) dapat dijelaskan kinerja keuangan perusahaan dari rasio solvabilitas pada PT Clipan Finance Indonesia Tbk sebagai berikut. Kinerja keuangan PT Clipan Finance Indonesia Tbk sesuai dengan data hasil penelitian selama 5 tahun berdasarkan DAR menunjukkan peningkatan, kecuali pada tahun 2015 ke 2016 terjadi penurunan yang tidak begitu signifikan, pada tahun 2015 nilai DAR sebesar 45,85\%, lalu menurun pada tahun 2016 menjadi $43,67 \%$ yang disebabkan oleh total hutang menurun sedangkan total aset meningkat. Pada 3 tahun berikutnya tahun 2017-2019 DAR meningkat. Tahun 2017 sebesar 59,26\%, tahun 2018 sebesar $60,76 \%$ dan tahun 2019 sebesar $61,17 \%$ yang artinya total hutang perusahaan sebesar $61,17 \%$ dari total aktiva, artinya setiap Rp. 1,- total aset menjamin hutang sebesar Rp. 0,61.-, hal ini berarti kinerja perusahaan belum konsisten diukur melalui DAR mempertahankan penurunan nilai DAR, bahkan pada tiga tahun terakhir nilai DAR semakin tinggi. Walaupun demikian nilai DAR masih tergolong rendah bahkan berada pada angka kurang dari satu (<1) atau $100 \%$ yang berarti memiliki perspektif mampu memenuhi kewajiban jangka panjang dan kewajiban jangka pendek yang baik. 
Untuk Debt Equity Ratio (DER) PT Clipan Finance Indonesia Tbk selama periode tahun 2015 sampai dengan 2019 menunjukkan hasil yang juga cenderung meningkat. Tahun 2015 DER sebesar 84,68\% lalu pada tahun 2016 terjadi penurunan menjadi 77,53\% dan seterusnya cenderung meningkat secara signifikan sampai dengan tahun 2019. DER mencapai nilai $157,51 \%$ di tahun 2019 artinya bahwa perusahaan memiliki hutang sebanyak 1,57 kali dari total modal $(1,57: 1)$ atau dengan kata lain bahwa setiap Rp. 1 utang hanya dijamin oleh Rp. 0,64 modal. Peningkatan DER disebabkan oleh adanya peningkatan modal yang diikuti dengan peningkatan total hutang. Dilihat dari total DER PT Clipan Finance Indonesia Tbk cukup tinggi, karena semakin tinggi DER menunjukkan perusahaan semakin berisiko. Hasil komparatif waktu rasio solvabilitas PT Clipan Finance Indonesia.Tbk yang diukur dengan DAR dan DER, rasio paling baik ada pada tahun 2016 karena memiliki nilai DAR paling rendah sebesar 43,67\% yang disebabkan karena nilai hutangnya lebih kecil dari total asetnya dan DER sebesar 77,53\%.

\section{PT Adira Dinamika Multi Finance Tbk}

Berdasarkan hasil perhitungan rasio solvabilitas yang diukur menggunakan Debt to Asset Ratio (DAR) dan Debt to Equity Ratio (DER) dapat dijelaskan kinerja keuangan perusahaan dari rasio solvabilitas pada PT Adira Dinamika Multi Finance Tbk sebagai berikut. Kinerja keuangan PT Adira Dinamika Multi Finance Tbk sesuai dengan data hasil penelitian selama 5 tahun berdasarkan DAR menunjukkan penurunan dari tahun 2015 ke 2019. Pada tahun 2015 nilai DAR sebesar $84,28 \%$ lalu menurun sampai 76,99\% di tahun 2019 yang artinya total hutang perusahaan sebesar $76,99 \%$ dari total asetnya, artinya setiap Rp. 1,- total aset menjamin hutang sebesar Rp. 0,77,-. Dengan penurunan DAR yang konsisten setiap tahunnya menandakan kinerja perusahaan dalam kondisi yang baik dan nilai DAR PT Adira Dinamika Multi Finance Tbk masih tergolong rendah bahkan berada pada angka kurang dari satu $(<1)$ atau $100 \%$ yang berarti memiliki perspektif kemampuan pemenuhan kewajiban jangka panjang dan kewajiban jangka pendek yang baik.

Untuk Debt Equity Ratio (DER) PT Adira Dinamika Multi Finance Tbk selama periode tahun 2015 sampai dengan 2019 menunjukkan hasil yang juga menurun setiap tahunnya. Pada tahun 2015 nilai DER sebesar $536,22 \%$ lalu menurun sampai $334,68 \%$ di tahun 2019 yang artinya bahwa perusahaan memiliki hutang sebanyak 3,35 kali dari total modal $(3,35: 1)$ atau dengan kata lain bahwa setiap Rp. 1 utang hanya dijamin oleh Rp. 0,29 modal. Penurunan DER disebabkan oleh peningkatan total modalnya lebih besar dibandingkan total hutangnya. Walaupun terus mengalami penurunan dengan nilai DER cukup tinggi. Dilihat dari total DER PT Adira Dinamika Multiartha Tbk yang cukup tinggi, karena semakin tinggi DER menunjukkan perusahaan semakin berisiko. Hasil komparatif waktu rasio solvabilitas PT Adira Dinamika Multi Finance Tbk yang diukur dengan DAR dan DER rasio paling baik ada pada tahun 2019 karena memiliki DAR paling rendah sebesar 76,99\% yang disebabkan karena nilai hutangnya lebih kecil dari total asetnya dan DER sebesar $334,68 \%$.

\section{PT Wahana Ottomitra Multiartha Tbk}

Berdasarkan hasil perhitungan rasio solvabilitas yang diukur menggunakan Debt to Asset Ratio (DAR) dan Debt to Equity Ratio (DER) dapat dijelaskan kinerja keuangan perusahaan dari rasio solvabilitas pada PT Wahana Ottomitra Multiartha Tbk sebagai berikut. Kinerja keuangan PT Wahana Ottomitra Multiartha Tbk sesuai dengan data hasil penelitian selama 5 tahun berdasarkan DAR berfluktuatif tetapi cenderung menurun pada 3 tahun terakhir. Pada tahun 2015 nilai DAR sebesar $85,76 \%$ lalu meningkat menjadi 87,78\% pada tahun 2017 yang disebabkan oleh kenaikan total hutang yang lebih besar dibandingkan dengan kenaikan total asetnya. Untuk selanjutnya DAR menurun sampai $83,43 \%$ di tahun 2019 yang artinya total hutang perusahaan sebesar $83,43 \%$ dari total aktiva, artinya setiap Rp. 1,- total aset menjamin hutang sebesar Rp. 0,83.-. Walaupun berfluktuatif tetapi DAR PT Wahana Ottomitra Multiartha Tbk cenderung mengalami penurunan walaupun tidak terlalu signifikan. nilai DAR PT Wahana Ottomitra Multiartha Tbk tergolong masih rendah, karena masih dibawah angka 1 atau $100 \%$ yang berarti masih mampu dalam pemenuhan kewajiban jangka panjang dan kewajiban jangka pendek dengan terus konsisten dalam menjaga penurunan rasio hutang terhadap asetnya.

Untuk Debt Equity Ratio (DER) PT Wahana Ottomitra Multiartha Tbk selama periode tahun 2015 sampai dengan 2019 menunjukkan hasil yang juga cenderung fluktuatif. Pada tahun 2015 DER sebesar $602,27 \%$, lalu mengalami peningkatan menjadi sebesar 718,22\% pada tahun 2016 yang disebabkan oleh kenaikan total hutang yang lebih besar dibandingkan dengan kenaikan modalnya. 3 tahun berikutnya DER mengalami penurunan hingga sebesar 503,48\% \% yang artinya bahwa perusahaan memiliki hutang sebanyak 5,03 kali dari total modal $(5,03: 1)$ atau dengan kata lain bahwa setiap Rp. 1 utang hanya dijamin oleh Rp. 0,20 modal. Penurunan 
nilai DER selama 3 tahun terakhir dikarenakan kenaikan ekuitas lebih besar di bandingkan kenaikan total hutangnya. Walaupun terus mengalami penurunan total DER PT Wahana Ottomitra Multiartha Tbk masih terlalu tinggi, karena semakin tinggi DER menunjukkan semakin berisiko. Hasil komparatif waktu rasio solvabilitas PT Wahana Ottomitra Multiartha Tbk yang diukur dengan DAR dan DER memiliki rasio paling baik ada pada tahun 2019 karena memiliki DAR paling rendah sebesar $83,43 \%$ yang disebabkan karena nilai hutangnya lebih kecil dari total asetnya dan DER sebesar 503,48\%.

\section{Pembahasan Komparatif Solvabilitas Perusahaan}
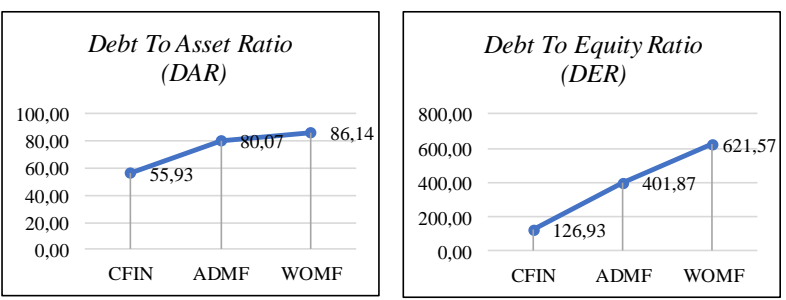

Sumber : Data Diolah

\section{Gambar 3. Grafik Hasil Komparatif Rasio Solvabilitas Perusahaan}

Dari hasil komparatif masing-masing perusahaan dengan industri sejenis menunjukkan bahwa dari hasil perhitungan rasio solvabilitas yang dihitung menggunakan dengan DAR dan DER, perusahaan yang memiliki DAR dan DER paling baik adalah PT Clipan Finance Indonesia Tbk karena memiliki rasio rasio terendah diantara perusahaan lainnya sebesar $55,93 \%$ untuk DAR dan $126,93 \%$ untuk DER.

\section{Pembahasan Masing-masing Rasio Aktivitas Peru- sahaan Dan Komparatifnya}

\section{Tabel 3 Hasil Perhitungan Rasio Aktivitas}

\begin{tabular}{|c|c|c|c|c|c|c|}
\hline \multirow{4}{*}{ Tahun } & \multicolumn{5}{|c|}{$\begin{array}{c}\text { Rasio Aktivitas } \\
\text { (Hasil Data Berdasarkan Berapa Kali Perputaran) }\end{array}$} & \\
\hline & \multicolumn{2}{|c|}{ CFIN } & \multicolumn{2}{|c|}{ ADMF } & \multicolumn{2}{|c|}{ WOMF } \\
\hline & Receirable & Total Asset & Receivable & Total Asset & Receivinble & Total Asset \\
\hline & $\begin{array}{l}\text { Twrin Over } \\
\text { (RTO) }\end{array}$ & $\begin{array}{l}\text { Turn Over } \\
\text { (TATO) }\end{array}$ & $\begin{array}{l}\text { Turn Over } \\
\text { (RTO) }\end{array}$ & $\begin{array}{l}\text { Turn 0ver } \\
\text { (IATO) }\end{array}$ & $\begin{array}{l}\text { Turn Over } \\
\text { (RTO) }\end{array}$ & $\begin{array}{l}\text { Turn Over } \\
\text { (TATO) }\end{array}$ \\
\hline 2015 & 0,17 & 0,17 & 0,30 & 0,28 & 0,40 & 0,33 \\
\hline 2016 & 0,16 & 0,15 & 0,33 & 0,30 & 0,38 & 0,32 \\
\hline 2017 & 0,18 & 0,17 & 0,36 & 0,32 & 0,34 & 0,30 \\
\hline 2018 & 0,19 & 0,18 & 0,38 & 0,33 & 0,37 & 0,32 \\
\hline 2019 & 0,20 & 0,19 & 0,39 & 0,34 & 0,37 & 0,31 \\
\hline
\end{tabular}

Sumber : Data Diolah

\section{PT Clipan Finance Indonesia Tbk}

Berdasarkan data hasil penelitian rasio aktivitas diatas dapat dijelaskan kinerja keuangan perusahaan dari rasio profitabilitas pada PT Clipan Finance Indonesia Tbk sebagai berikut. Kinerja keuangan PT Clipan Finance Indonesia Tbk sesuai dengan data hasil penelitian selama 5 tahun berdasarkan Receivable Turn Over (RTO) berfluktuatif tetapi cenderung meningkat pada 3 tahun terakhir. Pada tahun 2015 RTO sebesar 0,17 kali perputaran, lalu pada tahun 2016 RTO menurun yang tidak signifikan yaitu sebesar 0,16 kali perputaran, hal ini disebabkan pendapatan usaha menurun dari tahun sebelumnya. Dan 3 tahun selanjutnya sampai tahun 2019 RTO menjadi sebesar 0,20 kali perputaran yang artinya bahwa dalam setahun PT Clipan Finance Indonesia Tbk mampu merubah piutang menjadi kas sebanyak 0,20 kali yang didapat dari total penjualan atau pendapatan usaha dibagi dengan rata-rata piutang tahun 2019. Dengan demikian RTO PT Clipan Finance Indonesia cukup konsisten dalam peningkatannya. Karena Pada dasarnya setiap perusahaan pembiayaan ingin menagih piutang dengan cepat, sehingga dapat mengurangi risiko piutang yang bermasalah dan tak tertagih.

Untuk Total Asset Turn Over (TATO) dari tahun 2015 sampai dengan 2019 menunjukkan kondisi fluktuatif cenderung meningkat pada 3 tahun terakhir. Pada tahun 2015 TATO sebesar 0,17 kali perputaran, lalu turun tidak signifikan menjadi sebesar 0,15 kali perputaran di tahun 2016. Dan terus meningkat menjadi sebesar 0,19 di tahun 2019, hal ini menunjukkan peningkatan perusahaan dalam menggunakan asetnya untuk menghasilkan pendapatan dengan kata lain dana yang tertanam dalam keseluruhan rata-rata total aset dalam satu tahun berputar 0,19 kali atau setiap rupiah aset selama satu tahun menghasilkan pendapatan sebesar Rp. 0,19,-. Hasil komparatif waktu rasio aktivitas PT Clipan Finance Indonesia Tbk yang diukur dengan RTO dan TATO memiliki rasio paling baik ada pada tahun 2019 karena memiliki RTO tertinggi sebesar 0,20 kali dan TATO sebesar 0,19 kali.

\section{PT Adira Dinamika Multi Finance Tbk.}

Berdasarkan data hasil penelitian rasio aktivitas dapat dijelaskan kinerja keuangan perusahaan dari rasio profitabilitas pada PT Adira Dinamika Multi Finance Tbk sebagai berikut. Kinerja keuangan PT Adira Dinamika Multi Finance Tbk sesuai dengan data hasil penelitian selama 5 tahun berdasarkan Receivable Turn Over (RTO) menunjukkan peningkatan setiap tahunnya. Pada tahun 2015 yaitu sebesar 0,30 kali perputaran piutang dalam waktu satu 
tahun, lalu mengalami peningkatan di tahun 2016 menjadi $0,33 \mathrm{kali}$, dan terus meningkat sampai 0,39 kali perputaran piutang di tahun 2019 yang artinya bahwa dalam setahun PT Adira Dinamika Multi Finance Tbk mampu merubah piutang menjadi kas sebanyak 0,39 kali yang didapat dari total penjualan atau pendapatan usaha dibagi dengan rata-rata piutang. Dilihat dari peningkatannya setiap tahun yang konsisten, maka RTO dapat dikatakan baik, karena semakin tinggi nilai RTO maka semakin baik. Hal tersebut menunjukkan bahwa semakin rendah dana yang ditanam dalam piutang.

Untuk Total Asset Turn Over (TATO) dari tahun 2015 sampai dengan 2019 juga menunjukkan peningkatan setiap tahunnya. Pada tahun 2015 nilai TATO sebesar 0,28 kali lalu, tahun 2016 TATO mengalami peningkatan yaitu sebesar 0,30 kali perputaran, dan terus meningkat sampai 0,34 kali perputaran di tahun 2019 yang artinya setiap Rp. 1 asetnya hanya mampu menghasilkan pendapatan sebesar Rp. 0,34. Dengan peningkatan TATO yang konsisten maka menunjukkan peningkatan perusahaan dalam dalam menggunakan asetnya untuk menghasilkan pendapatan. Hasil komparatif waktu rasio aktivitas PT Adira Dinamika Multi Finance Tbk yang diukur dengan RTO dan TATO, rasio paling baik ada pada tahun 2019 karena memiliki RTO tertinggi sebesar 0,39 kali dan TATO sebesar 0,34 kali.

\section{PT Wahana Ottomitra Multiartha Tbk.}

Berdasarkan data hasil penelitian rasio aktivitas dapat dijelaskan kinerja keuangan perusahaan dari rasio aktivitas pada PT Wahana ottomitra multiartha Tbk sebagai berikut. Kinerja keuangan PT Wahana Ottomitra Multiartha Tbk sesuai dengan data hasil penelitian selama 5 tahun berdasarkan Receivable Turn Over (RTO) menunjukkan berfluktuatif cenderung menurun. Pada tahun 2015 RTO sebesar 0,41 kali, lalu mengalami penurunan selama 2 tahun menjadi sebesar 0,34 kali pada tahun 2017 dan selanjutnya terus meningkat menjadi 0,37 kali perputaran piutang di tahun 2019 yang artinya bahwa dalam setahun PT Wahana Ottomitra Multiartha Tbk mampu merubah piutang menjadi kas sebanyak 0,37 kali yang didapat dari total penjualan atau pendapatan usaha dibagi dengan rata-rata piutang tahun 2019. Dengan demikian RTO PT Wahana Ottomitra Multiartha belum konsisten dalam meningkatkan rasio perputaran piutang setiap tahunnya.

Untuk Total Asset Turn Over (TATO) dari tahun 2015 sampai dengan 2019 juga berfluktuatif. Pada tahun 2015 nilai TATO sebesar 0,33 kali, lalu mengalami penurunan sebesar 0,32 kali pada tahun
2016, penurunan kembali di tahun 2017 menjadi 0,30 kali. Setelah itu mengalami peningkatan pada tahun 2018 tetapi tidak begitu signifikan TATO kembali menjadi 0,32 tahun 2018 dan menurun kembali menjadi 0,31 kali pada tahun 2019 yang artinya setiap Rp. 1 aktiva perusahaan hanya mampu menghasilkan pendapatan sebesar Rp. 0,31. Dengan demikian hasil TATO belum konsisten dalam mengelolah asetnya. Karena masih banyak dana yang tertanam dalam asetnya yang menganggur, ini dapat dilihat dari pendapatan yang dihasilkan cukup rendah dan mengalami peningkatan dan penurunan dari tahun 2015 sampai tahun 2019. Hasil komparatif waktu rasio aktivitas PT Wahana Ottomitra Multiartha Tbk yang diukur dengan RTO dan TATO rasio paling baik ada pada tahun 2015 karena memiliki RTO tertinggi sebesar 0,41 kali dan TATO sebesar 0,33 kali.

\section{Pembahasan Komparatif Rasio Aktivitas Perusahaan}

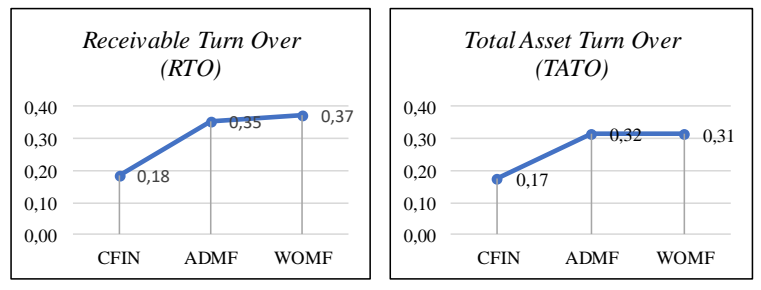

Sumber : Data Diolah

\section{Gambar 4. Grafik Hasil Komparatif Rasio Aktivitas Perusahaan}

Dari hasil komparatif masing-masing perusahaan dengan industri sejenis menunjukkan bahwa dari hasil perhitungan rasio aktivitas yang dihitung menggunakan dengan Receivable Turn Over (RTO) dan Total Asset Turn Over (TATO) perusahaan yang memiliki RTO paling baik adalah PT Wahanna Ottomitra Multiartha Tbk sebesar 0,37 kali dan untuk TATO paling tinggi adalah PT Adira Dinamika Multi Finance Tbk sebesar 0,32 kali.

Pembahasan Masing-masing Rasio Profitabilitas Perusahaan Dan Komparatifnya Tabel 4. Hasil Perhitungan Rasio Profitabilitas

\begin{tabular}{|c|c|c|c|c|c|c|}
\hline \multirow{4}{*}{ Tahun } & \multicolumn{5}{|c|}{$\begin{array}{c}\text { Rasio Aktivitas } \\
\text { (Hasil Data Berdasarkan Berapa Kali Perputaran) }\end{array}$} & \\
\hline & \multicolumn{2}{|c|}{ CFIN } & \multicolumn{2}{|c|}{ ADMF } & \multicolumn{2}{|c|}{ WOMF } \\
\hline & Receivable & Total Asset & Reciviable & Total Asset & Recervable & Total Asset \\
\hline & $\begin{array}{l}\text { Turn Over } \\
\text { (RTO) }\end{array}$ & $\begin{array}{l}\text { Turn Over } \\
\text { (TATO) }\end{array}$ & $\begin{array}{l}\text { Turn Over } \\
\text { (RTO) }\end{array}$ & $\begin{array}{l}\text { Turn Over } \\
\text { (TATO) }\end{array}$ & $\begin{array}{l}\text { Turn Over } \\
\text { (RTO) }\end{array}$ & $\begin{array}{l}\text { Turn Over } \\
\text { (TATO) }\end{array}$ \\
\hline 2015 & 4,31 & 7,96 & 2,40 & 15,25 & 0,30 & 2,07 \\
\hline 2016 & 3,05 & 5,41 & 3,65 & 20,28 & 0,90 & 7,40 \\
\hline 2017 & 2,39 & 5,86 & 4,78 & 24,53 & 2,33 & 18,25 \\
\hline 2018 & 2,75 & 7,02 & 5,76 & 25,83 & 2,44 & 18,37 \\
\hline 2019 & 2,98 & 7,68 & 6,00 & 26,10 & 3,14 & 18,95 \\
\hline
\end{tabular}

Sumber : Data Diolah 


\section{PT Clipan Finance Indonesia Tbk}

Berdasarkan data hasil penelitian rasio profitabilitas dapat dijelaskan kinerja keuangan perusahaan dari rasio profitabilitas pada PT Clipan Finance Indonesia Tbk sebagai berikut. Kinerja keuangan PT Clipan Finance Indonesia Tbk sesuai dengan data hasil penelitian selama 5 tahun berdasarkan Return On Asset (ROA) berfluktuatif. Pada tahun 2015 ROA sebesar $4,31 \%$ lalu menurun menjadi $3,05 \%$ di tahun 2016. Penurunan disebabkan karena total aset meningkat sedangkan laba bersih mengalami penurunan. Dan 3 tahun selanjutnya terus meningkat sampai sebesar 2,98\% pada tahun 2019 yang artinya bahwa setiap Rp. 1 total aset turut berkontribusi menciptakan Rp. 0,0298 laba bersih. Walaupun terus mengalami peningkatan dalam 3 tahun terakhir nilai ROA PT Clipan Finance Indonesia.Tbk masih tergolong rendah karena masih belum konsisten dalam meningkatkan nilai ROA, karena semakin tinggi ROA menunjukkan perusahaan semakin efektif menghasilkan laba bersih atas aset yang dimiliki perusahaan dan menunjukkan kemampuan perusahaan yang lebih besar dalam menghasilkan keuntungan dengan menggunakan keseluruhan aset yang dimiliki.

Untuk Return On Equity (ROE) PT Clipan Finance Indonesia Tbk selama periode tahun 2015 sampai dengan 2019 menunjukkan hasil yang juga cenderung fluktuatif. Pada tahun 2015 ROE sebesar 7,97\% lalu menurun pada tahun 2016 menjadi sebesar 5,41\% . Penurunan disebabkan karena penurunan laba bersih sedangkan total modalnya meningkat. Dan 3 tahun selanjutnya ROE terus meningkat sampai sebesar 7,68\% di tahun 2019 yang artinya setiap Rp. 1 ekuitas menghasilkan laba bersih atau total keuntungan sebesar Rp. 0,078,-. Dengan demikian untuk ROE tergolong cukup baik dalam meningkatkan rasionya. Karena ROE merupakan rasio keuangan yang digunakan untuk mengukur kinerja perusahaan khususnya menyangkut profitabilitas perusahaan. Semakin tinggi ROE menunjukkan perusahaan memiliki kemampuan yang baik dalam menghasilkan laba. Hasil komparatif waktu rasio profitabilitas PT Clipan Finance Indonesia Tbk yang diukur berdasarkan ROA dan ROE rasio paling baik ada pada tahun 2015 karena memiliki ROA tertinggi sebesar 4,31\% dan ROE sebesar 7,96.

\section{PT Adira Dinamika Multi Finance Tbk}

Berdasarkan data hasil penelitian rasio profitabilitas yang telah diuraikan diatas dapat dijelaskan kinerja keuangan perusahaan dari rasio profitabilitas pada PT Adira Dinamika Multi Finance Tbk sebagai berikut. Kinerja keuangan PT Adira Dinamika Multi
Finance Tbk sesuai dengan data hasil penelitian selama 5 tahun berdasarkan Return On Asset (ROA) menunjukkan peningkatan. Pada tahun 2015 ROA sebesar 2,40\% lalu meningkat sampai tahun 2019 menjadi sebesar 6,00\% yang artinya setiap Rp. 1 total aset maka turut berkontribusi menciptakan Rp. 0,06,laba bersih. Peningkatan ROA disebabkan karena peningkatan laba bersih yang signifikan setiap tahunnya dibandingkan peningkatan total asetnya, ROA PT Adira Dinamika Multi Finance Tbk tergolong baik karena konsisten meningkat setiap tahunnya. Semakin tinggi ROA menunjukkan perusahaan semakin efektif menghasilkan laba bersih atas aset yang dimiliki perusahaan dan menunjukkan kemampuan perusahaan yang lebih besar dalam menghasilkan keuntungan dengan menggunakan keseluruhan aset yang dimiliki.

Untuk Return On Equity (ROE) PT Adira Dinamika Multi Finance Tbk selama periode tahun 2015 sampai dengan 2019 menunjukkan hasil yang juga meningkat setiap tahunnya. Pada tahun 2015 nilai ROE sebesar $15,25 \%$ dan terus meningkat sampai tahun 2019 nilai rasionya menjadi sebesar $26,10 \%$ yang artinya setiap Rp. 1 ekuitas menghasilkan laba bersih atau total keuntungan sebesar Rp. 0,261,-. ROE PT Adira Dinamika Multi Finance Tbk tergolong baik karena konsisten meningkat setiap tahunnya, hal ini disebabkan adanya kestabilan antara peningkatan laba bersih dengan peningkatan total aset perusahaan. Hasil komparatif waktu rasio profitabilitas PT Adira Dinamika Multi Finance Tbk yang diukur berdasarkan ROA dan ROE, rasio paling baik ada pada tahun 2019 karena memiliki ROA tertinggi sebesar 6\% dan ROE sebesar 26,10\%.

\section{PT Wahana Ottomitra Multiartha Tbk}

Berdasarkan data hasil penelitian rasio profitabilitas dapat dijelaskan kinerja keuangan perusahaan dari rasio profitabilitas pada PT Wahana Ottomitra Multiartha Tbk sebagai berikut. Kinerja keuangan PT Wahana Ottomitra Multiartha Tbk sesuai dengan data hasil penelitian selama 5 tahun berdasarkan Return On Asset (ROA) menunjukkan peningkatan. Pada tahun 2015 ROA sebesar $0,30 \%$ dan terus meningkat setiap tahunnya menjadi sebesar 3,14\% pada tahun 2019 artinya setiap Rp. 1 total aset maka turut berkontribusi menciptakan Rp. 0,0314,-laba bersih. Peningkatan ROA disebabkan karena peningkatan laba bersih yang signifikan setiap tahunnya dibandingkan peningkatan total asetnya. Peningkatan yang konsisten pada ROA setiap tahunnya tergolong baik. Karena, semakin tinggi rasio ROA menunjukkan perusahaan semakin efektif menghasilkan laba bersih atas aset yang dimiliki 
perusahaan dan menunjukkan kemampuan perusahaan yang lebih besar dalam menghasilkan keuntungan dengan menggunakan keseluruhan aset yang dimiliki.

Untuk Return On Equity (ROE) PT Wahana Ottomitra Multiartha Tbk selama periode tahun 2015 sampai dengan 2019 menunjukkan hasil yang juga meningkat secara signifikan. Pada tahun 2015 rasio ROE sebesar 2,07 lalu terus meningkat mencapai 18,95\% pada tahun 2019 yang artinya setiap Rp. 1 ekuitas menghasilkan laba bersih atau total keuntungan sebesar Rp. 0,819,-. Dengan meningkatnya ROE secara konsisten, hal ini disebabkan adanya kestabilan antara peningkatan laba bersih dengan peningkatan total aset perusahaan. Hasil komparatif waktu rasio profitabilitas PT Wahana Ottomitra Multiartha Tbk yang diukur berdasarkan ROA dan ROE, rasio paling baik ada pada tahun 2019 karena memiliki rasio ROA tertinggi sebesar 3,14 dan ROE sebesar 18,95\%.

\section{Pembahasan Komparatif Rasio Profitabilitas Perusahaan}
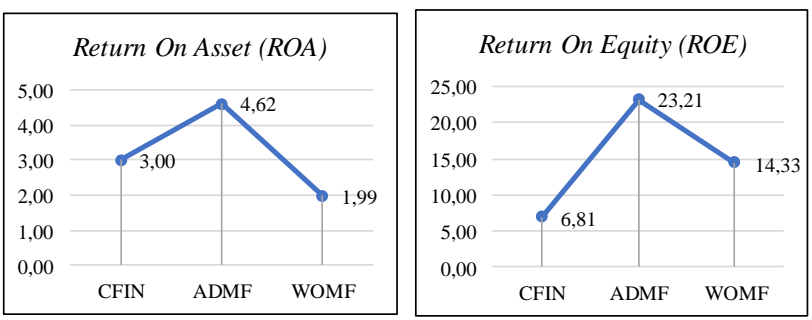

Sumber : Data Diolah

\section{Gambar 5 Grafik Hasil Komparatif Rasio Profitabilitas Perusahaan}

Dari hasil komparatif masing-masing perusahaan dengan industri sejenis menunjukkan bahwa dari hasil perhitungan rasio profitabilitas yang dihitung menggunakan dengan Return On Asset (ROA) dan Return On Equity (ROE) perusahaan yang memiliki rasio paling baik adalah PT Adira Dinamika Multi Finance Tbk karena memiliki rasio ROA tertinggi diantara perusahaan lainnya sebesar $4,62 \%$ dan $23,21 \%$ untuk ROE.

Peringkat skor rasio Likuiditas, Solvabilitas, Aktivitas dan Profitabilitas Perusahaan

\section{Multifinance.}

Penilaian skor dalam penelitian ini menggunakan menggunakan skala rasio dan skala ordinal. Menurut Sugiyono (2019:13) skala rasio adalah skala kuantitatif kontinum yang jaraknya sama dan mempunyai nilai absolut/mutlak. Sedangkan menurut
Umar (2013:46) skala rasio yaitu ukuran yang mempunyai nilai nol yang sama dan dapat diperbandingkan.

Untuk skala ordinal menurut Sugiyono (2019:11) adalah skala pengukuran yang tidak hanya menyatakan kategori, tetapi juga menyatakan peringkat/ranking. Sedangkan menurut Umar (2013:44) skala ordinal adalah skala yang mengurutkan data dari tingkat yang paling rendah ke tingkat yang paling tinggi atau sebaliknya dengan interval yang tidak harus sama.

Skala pengukuran dalam penelitian ini dinyatakan dalam bentuk angka 1 sampai 3 . Dimana angka 1 menunjukkan tingkat pilihan yang pertama yaitu sangat baik dari perusahaan sampel yang lain. Dan angka 2 menunjukkan pilihan kedua yaitu baik, lalu angka 3 menunjukkan pilihan terakhir yaitu cukup baik diantara perusahaan sampel dengan industri sejenis. Berikut dibawah ini perhitungan skor dari tahun 2015 sampai dengan tahun 2019 dengan menggunakan skor peringkat 1 (satu) sampai dengan peringkat 3 (tiga):

Tabel 5. Hasil Skor Peringkat Perusahaan Multifinance Tahun 2015-2019

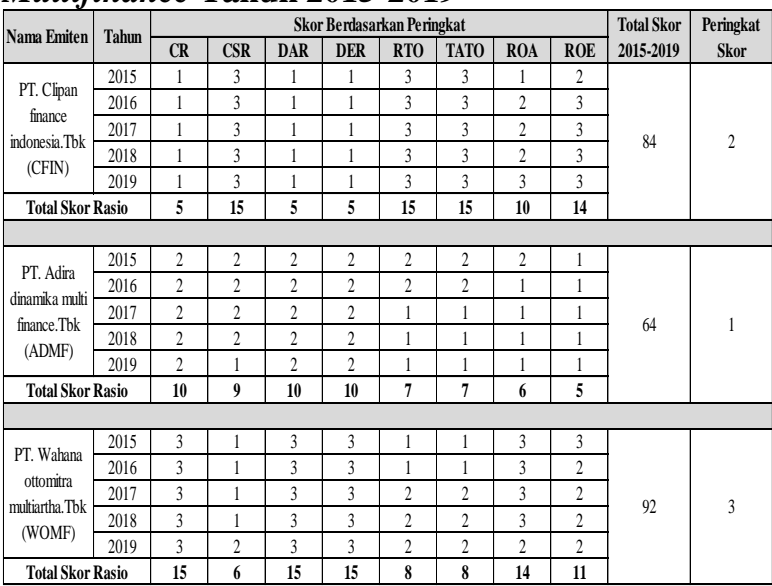

Sumber : Data Diolah

Dari hasil total skor pada tabel 4.9 menunjukkan bahwa perusahaan perusahaan sampel dengan industri sejenis yang memiliki peringkat nomor 1 (satu) atau peringkat sangat baik dari tahun 2015 sampai dengan tahun 2019 adalah PT Adira Dinamika Multi Finance Tbk karena memiliki total skor paling sedikit sebesar 64 skor, yang artinya bahwa PT Adira Dinamika Multi Finance Tbk memiliki kinerja keuangan yang sangat baik dari 2 (dua) perusahaan industri sejenis yang dijadikan sampel. Lalu peringkat skor nomor 2 (dua) adalah PT Clipan Finance Indonesia Tbk yang memiliki nilai skor sebesar 84 skor yang artinya bahwa PTClipan Finance Tbk Indonesia memiliki 
kinerja keuangan yang baik, tetapi tidak lebih baik dari PT Adira Dinamika Multi Finance Tbk namun lebih baik dari PT Wahana Ottomitra Multiartha Tbk. Dan posisi terakhir dengan total skor 92 di tempati oleh PT Wahana Ottomitra Multiartha Tbk yang memiliki kinerja keuangan cukup baik dari ketiga perusahaan industri sejenis yang menjadi sampel dalam penelitian ini.

\section{SIMPULAN DAN SARAN}

Kesimpulan hasil penelitian ini dapat dikemukakan sebagai berikut:

1) Perusahaan multifinance dengan rasio likuiditas terbaik selama periode tahun 2015 sampai 2019 yang diukur dengan current ratio adalah PT Clipan Finance Indonesia Tbk dengan nilai rasio tertinggi sebesar $230,15 \%$, sedangkan yang diukur dengan cash ratio adalah PT Wahana Ottomitra Multiartha Tbk dengan nilai rasio tertinggi sebesar $13,44 \%$. Untuk perusahaan dengan rasio solvabilitas terbaik selama periode tahun 2015 sampai 2019 yang diukur dengan debt to asset ratio dan debt to equity ratio adalah PT Clipan Finance Indonesia Tbk dengan nilai rasio terendah sebesar 55,93\% dan 126,93\%. Dan perusahaan dengan rasio aktivitas terbaik selama periode tahun 2015 sampai 2019 yang diukur dengan receivable turn over adalah PT Wahana Ottomitra Multiartha Tbk dengan nilai rasio tertinggi sebesar 0,37 kali, sedangkan yang diukur dengan total asset turn over adalah PT Adira Dinamika Multi Finance Tbk dengan nilai rasio tertinggi sebesar 0,32 kali. Terakhir untuk perusahaan dengan rasio profitabilitas terbaik selama periode tahun 2015 sampai 2019 yang diukur dengan return on asset dan return on equity adalah PT Adira Dinamika Multi Finance Tbk dengan nilai rasio sebesar $4,62 \%$ dan $23,21 \%$.

2) Perbandingan kinerja ketiga perusahaan multifiance dari hasil peringkat skor rasio likuiditas, solvabilitas, aktivitas dan profitabilitas menunjukkan PT Adira Dinamika Multi Finance memiliki kinerja keuangan yang sangat baik dengan total 64 skor, PT Clipan Finance Indonesia memiliki kinerja keuangan yang baik dengan 84 skor dan PT Wahana Ottomitra Multiartha memiliki kinerja keuangan yang cukup baik dengan total 92 skor.

\section{SARAN}

Berdasarkan hasil analisis dan kesimpulan yang telah dilakukan, maka saran yang diajukan peneliti adalah sebagai berikut:

1) Bagi Perusahaan berdasarkan rasio likuiditas dan solvabilitas ketiga perusahaan multifinance dalam rangka untuk mengurangi hutang atau memenuhi kewajibannya sebaiknya mencari sumber dana yang paling kompetitif seperti menjual saham, mengoptimalkan pendanaan dari induk perbankannya dan memaksimalkan pemanfaatan modal sendiri sehingga meningkatkan jumlah pendapatan dan laba agar tidak kesulitan dalam melunasi hutanghutangnya. Ketiga perusahaan multifinance juga harus memperhatikan rasio aktivitas, khususnya jumlah pengumpulan piutang dengan cara memperbaiki strategi collection dan lebih selektif dalam pemberian kredit terhadap debitur agar memberikan kualitas pembiayaan yang semakin baik dan menghindari adanya kredit macet. Dan untuk mencapai tingkat profitabilitas yang maksimal, sebaiknya ketiga perusahaan multifinance melakukan efisiensi operasionalnya, meningkatkan penyaluran kredit, melakukan perbaikan kinerja diseluruh wilayah operasional persahaan dan mengedepankan penggunaan teknologi digital.

2) Untuk penelitian selanjutnya diharapkan untuk memperluas jangkauan penelitian dengan menambah sampel serta memperbarui periode sampel.

3) Bagi Investor dan calon investor dalam mengambil keputusan berinvestasi pada perusahaan multifinance yang terdaftar di BEI, dapat memperhatikan kinerja keuangan perusahaan secara menyeluruh baik dari faktor internal maupun eksternal. Dari faktor internal, berdasarkan ukuran kinerja keuangan PT Adira dinamika Multi Finance Tbk memiliki kinerja keuangan yang sangat baik. Untuk faktor eksternal dapat dengan memperhatikan kebijakan pemerintah, situasi politik dan tingkat pertumbuhan ekonomi.

\section{DAFTAR PUSTAKA}

\section{BUKU}

Effendi, Rizal. 2015. Accounting principles, Berbasis SAK ETAP. Edisi revisi. Jakarta: PT Rajagrafindo Persada.

Fahmi,Irham. 2017. Analisis Kinerja keuangan Panduan bagi Akademis, Manajer, dan Investor untuk Menilai dan Menganalisis Bisnis dari Aspek Keuangan. Bandung : Alfabeta.

Harahap, Sofyan, Syafri. 2010. Analisis Kritis Atas Laporan Keuangan. Jakarta: Rajawali Persada.

Harahap. 2018. Analisis Kritis atas Laporan Keuangan. PT Raja Grafindo Persada.

Hery. 2015. Analisis Kinerja Manajemen. Jakarta: PT Grasindo.

Hery. 2015. Analisis Laporan Keuangan. Edisi 1. Yogyakarta: Center For Academic Publishing Services. 
Jumingan. 2011. Analisis Laporan Keuangan. Jakarta: Bumi Aksara.

Kasmir. 2015. Analisis Laporan Keuangan. Jakarta: Rajawali Pers.

Munawir, H.S. 2014. Analisa Laporan Keuangan. Yogyakarta: Penerbit Liberty. November 07, 2019.

Prastowo, Dwi. 2011. Analisis Laporan Keuangan : Konsep dan Aplikasi. Edisi Ketiga. Yogyakarta: Unit Penerbit dan Percetakan STIM YKPN.

Rudianto. 2013. Akuntansi Manajemen. Jakarta: Erlangga.

Sanusi, Anwar. 2016. Metodologi Penelitian Bisnis (Disertai Contoh Proposal Penelitian Bidang Ilmu Ekonomi dan Manajemen).Jakarta: Salemba Empat.

Soemarso. 2005. Akuntansi suatu pengantar. Edisi Lima Buku Dua. Jakarta: Salemba Empat.

Subramanyam, K.R. and Wild, John J. 2010. Analisis Laporan Keuangan. Diterjemahkan oleh: Dewi Yanti. Edisi 10-Buku 1. Jakarta: Salemba Empat

Subramanyam, K.R. 2017. Analisis Laporan Keuangan. Jakarta : Salemba Empat.

Sugiyono. 2019. Metode Penelitian Kuantitatif, Kualitatif, dan $R \& D$. Bandung: Alfabeta.

Umar, Husein. 2013. Metode Penelitian untuk Skripsi dan Tesis Bisnis. Edisi Kedua. Jakarta: Rajawali Pers.

Weygandt, J., Kimmel, P., \& Kieso, D. 2018. Pengantar Akuntansi 1. Jakarta: Salemba Empat.

Yadiati,Winwin. 2007. Teori Akuntansi: Suatu Pengantar. Edisi pertama. Jakarta: Kencana Prenada Media Group.

\section{JURNAL}

Dewi, M. 2017. Analisis Rasio Keuangan untuk Mengukur Kinerja Keuangan PT Smartfren Telecom, Tbk. Jurnal Penelitian Ekonomi Akuntansi (JENSI). Volume 1 Nomor 1.

Munarka, A. M. H., \& Adeningsih, S. 2014. Analisis Rasio Keuangan Untuk Menilai Kinerja Keuangan Pada PT. Adira Dinamika Multi Finance Yang Terdaftar Di Bursa Efek Indonesia. Jurnal Ekonomi Pembangunan. STIE Muhammadiyah Palopo, Volume 1 Nomor 2.

Yansi, N. H., dan Tetuko, B. 2015. Analisis Kinerja Keuangan PT Adira Dinamika Multi Finance Tbk
Dengan Analisis Rasio Dan Analisis Du Pont. Jurnal Ilmiah. Manajemen dan Bisnis Mercu Buana, Volume 1 Nomor 3.

\section{PERATURAN}

Ikatan Akuntansi Indonesia. PSAK No. 1 Tentang Laporan Keuangan - edisi revisi 2015. 2015. Jakarta: Dewan Standar Akuntansi Keuangan.

Ikatan Akuntansi Indonesia. PSAK No. 30 Tentang Sewa. 2012. Jakarta: Dewan Standar Akuntansi Keuangan.

Otoritas Jasa Keuangan. Peraturan Otoritas Jasa Keuangan No.29/POJK.05/2014 Tentang Penyelenggaraan Usaha Perusahaan Pembiayaan. Jakarta: Ketua Dewan Komisioner Otoritas Jasa Keuangan.

Otoritas Jasa Keuangan. Peraturan Otoritas Jasa Keuangan No.35/POJK.05/2018 Tentang Penyelenggaraan Usaha Perusahaan Pembiayaan. Jakarta: Ketua Dewan Komisioner Otoritas Jasa Keuangan.

\section{INTERNET}

Asosiasi Perusahaan Pembiayaan Indonesia. Sejarah multifinance. https://www.ifsa.or.id/id/about\#backgroundsectio n.

Ayuningtyas, Dwi. 2019. Moody's Sebut Multifinance RI Lebih Kuat dari India. Oktober 21, 2019. https://www.cnbcindonesia.com/market/ 2019102 1114 548-17 108654/moodys-sebut-multifinanceri-lebih-kuat-dari -india.

Bursa Efek Indonesia. Laporan Keuangan. https://www.idx.co.id/perusahaan tercatat/laporan-keuangan-dan-tahunan/.

Hidayat, Feriawan 2019. Persaingan Industri Pembiayaan Dinilai Semakin ketat, 07 Oktober, 2019. https://www.beritasatu.com/ekonomi/578643persaingan-industri-pembiayaan-dinilai-semakinketat.

Nurjoni. 2019. Kinerja Industri Multifinance Terpengaruh Perilaku Milenial. https://investor.id/finance/kinerja-industrimultifinance-terpengaruh-perilaku-milenial.

Otoritas Jasa Keuangan. Data dan Statistik Lembaga Pembiayaan. https://www.ojk.go.id/id/kanal/iknb/data-danstatistik/lembaga pembiayaan/default.aspx. 
PT Adira Dinamika Multi Finance Tbk. Laporan Keuangan dan Profil Perusahaan. https://www.adira.co.id/.

PT Clipan Finance Indonesia Tbk. Laporan Keuangan dan Profil Perusahaan. https://www.clipan.co.id/.

PT Wahana Ottomitra Multiartha Tbk. Laporan Keuangan Profil Perusahaan. https://www.wom.co.id/.

Situmorang, Anggun P. 2020. OJK: Virus Corona Tekan Kinerja Perusahaan. https://www.merdeka.com/uang/ojk-viruscorona-tekan-kinerja-perusahaanpembiayaan.html. 